\title{
Drying Characteristics and Mathematical Modeling of Without Pretreatment and Pretreatment Zucchini (Cucurbita Pepo L.) Slices in a Solar Tunnel Dryer
}

\author{
Sevil Karaaslan ${ }^{1 *}$, Kamil Ekinci², Barbaros S. Kumbul ${ }^{3}$

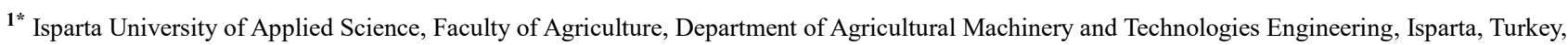 \\ (ORCID: 0000-0002-2289-8005), sevilkaraaslan@isparta.edu.tr \\ ${ }^{2}$ Isparta University of Applied Science, Faculty of Agriculture, Department of Agricultural Machinery and Technologies Engineering, Isparta, Turkey, \\ (ORCID: 0000-0002-7083-5199), kamilekinci@isparta.edu.tr \\ ${ }^{3}$ Isparta University of Applied Science, Faculty of Agriculture, Department of Agricultural Machinery and Technologies Engineering, Isparta, Turkey, \\ (ORCID: 0000-0002-7379-7597), barbarosskumbul@gmail.com
}

(First received 19 August 2021 and in final form 24 September 2021)

(DOI: 10.31590/ejosat.984997)

ATIF/REFERENCE: Karaaslan, S., Ekinci, K. \& Kumbul, B.S. (2021). Drying Characteristics and Mathematical Modeling of Without Pretreatment and Pretreatment Zucchini (Cucurbita Pepo L.) Slices in a Solar Tunnel Dryer. European Journal of Science and Technology, (27), 575-582.

\begin{abstract}
With/without pretreated zucchini samples were dried in a solar tunnel dryer to determine drying characteristic and modelling. Solar irradiation at ambient, drying air temperature and air velocity at specific intervals in various parts of the dryer were measured. In the study, it was investigated how pretreatment of zucchini affected the drying time, moisture ratio and drying rate of it in solar tunnel dryer. In addition, the data on the drying process were applied to eight different mathematical models (Newton, Page, Henderson and pabis, Logarithmic, Diffusion, Midilli et al., Alibas, Logistic Equation Models). The performance levels of the models compared according to $\mathrm{R}^{2}, \chi^{2}$, besides RMSE between moisture ratios that were observed and predicted. Furthermore, considering all selected models, Midilli et al. and Alibaş model equations gave the highest $\mathrm{R}^{2}$, the lowest $\chi^{2}$ and RMSE values and were found to reveal the ratio of drying in a satisfactory way for all the methods of drying.
\end{abstract}

Keywords: Solar tunnel dryer, Zucchini, Mathematical modelling.

\section{Ön İşlemsiz ve Ön işlemli Kabak (Cucurbita Pepo L.) Dilimlerinin Tünel Tipi Güneşli Kurutucuda Kurutma Özellikleri ve Matematiksel Modellemesi}

$\ddot{O} \mathbf{z}$

Ön işlemsiz ve ön işlemli kabak örnekleri, kurutma karakteristiği ve modellemeyi belirlemek için tünel tipi güneş enerjili kurutma yöntemi kullanılarak kurutulmuştur. Araştırmacılar, kurutucunun çeşitli bölümlerinde belirli aralıklarla ortam ve kurutma havası sıcaklıklarında ve hava hızında güneş ışınımını ölçmüştür. Çalışmada, güneş enerjisiyle kurutmanın ön işlemsiz ve ön işlemli kabak örneklerinin kuruma süresini, nem oranını ve kuruma hızını nasıl etkilediği araştırılmıştır. Ayrıca kurutma işlemine ilişkin veriler, Newton, Page, Henderson ve pabis, Logaritmik, Difüzyon, Midilli ve ark. Alibas, Lojistik isimli 8 farklı matematiksel modele uygulanmıştır. Araştırmacılar, modellerin performans düzeylerini korelasyon katsayısı $\left(\mathrm{R}^{2}\right)$, ki-kare değeri $\left(\chi^{2}\right)$ ve gözlemlenen ve tahmin edilen nem oranları arasındaki ortalama hata karesi (RMSE) ile karşılaştırmışlardır. Ayrıca, seçilen tüm modeller dikkate alındığında Midilli ve ark. ve Alibaş model denklemleri en yüksek $\mathrm{R}^{2}$, en düşük $\chi^{2}$ ve RMSE değerlerini vermiş ve tüm kurutma yöntemleri için kuruma oranını tatmin edici bir şekilde ortaya koyduğu bulunmuştur.

Anahtar Kelimeler: Tünel tipi güneşli kurutucu, Kabak, Matematiksel modelleme.

*Corresponding Author: sevilkaraaslan@isparta.edu.tr 


\section{Introduction}

Vegetables are often consumed raw in Turkey. Turkey has an important place in the world production of fresh vegetables. However, in recent years, the consumption of dry vegetables has increased gradually due to the fact that people prefer food that can be cooked more easily and quickly. They are highly preferred as they can be used directly in the production of dry vegetables, instant soups, baby food and sauces. Based on Food and Agriculture Organization (FAO), approximately $92 \%$ of our total dried vegetable exports are tomatoes. Other important dried vegetables in exports are mushrooms, eggplant and zucchini. According to the data of 2020, most of the dried eggplant was exported to Germany, followed by France and the Netherlands. Germany is the country where most of the exports are made in dried pumpkin, and France and Italy are in the second and third place (Kutlu, 2013).

Open sun drying is a primitive method used in most of the developing countries for drying many different products. However, the process takes a long time (approximately 10-15 days) due to uninterrupted solar energy, seasonal fluctuations and sudden rainfall, and thus the quality of the product is negatively affected. This negative situation can be eliminated by using solar drying technology (Karthikeyan and Murugavelh, 2018).

Tunnel and cabinet drying systems are the most used convective dryers for drying vegetables and fruits. Generally, this type of drying system is preferred more due to ease of design and economic reasons (Çetin, 2019).

Solar drying is a technique that has been used since ancient times to dry plants, seeds, vegetables, fruits, meat, fish, wood and other agricultural forest products. Passive solar cabinet dryers are generally simply built and inexpensive units with high applications for domestic purposes. These dryers with solar energy have a drying area of 1-2 $\mathrm{m}^{2}$ and a drying capacity of 10$20 \mathrm{~kg}$ and are suitable for drying various products. In the study by Mulato et al. (1999), a solar tunnel dryer with a drying capacity of $25 \mathrm{~kg} / \mathrm{m}^{2}$, built with an auxiliary fan, was tested in Indonesia.

Many studies have been reported in the literature with many different types of solar dryers used for drying various agricultural products such as chili pepper, red chili. (Rabha et al., 2017; Rabha and Muthukumar, (2017); Banout et al., (2011).

Main aims of this study were to; (1) dry zucchini slices in a solar tunnel dryer, (2) determine the effect of pretreatment on drying properties (3) fit eight semi-empirical film models to experimental drying data.

\section{Material and Method}

The zucchini (Cucurbita pepo) used in this study was purchased from a market in Isparta (Turkey). Then, the zucchini kept in the refrigerator at $4^{\circ} \mathrm{C}$ before drying, they were hand washed and filtered, peeled and cut into slices of about $50 \mathrm{~mm}$ in diameter and about 3, 6 and $9 \mathrm{~mm}$ thick using a kitchen slicer. The initial moisture content of zucchini was found to be $90.24 \pm 0.2$ $\%$ (w.b). Drying was continued to a final moisture content of about $10 \pm 0.5 \%$ (w.b.).
Boiling was carried out by soaking $100 \mathrm{~g}$ of zucchini samples in $200 \mathrm{~g}$ of boiling water for 2 minutes. The temperature of the water was $91.7^{\circ} \mathrm{C}$.

The solar tunnel solar dryer was designed and installed on the land by the Isparta University of Applied Sciences, Department of Agricultural Machinery and Technologies Engineering (Figure 1). The dryer used in the study consisted of a drying tunnel, a flat plate solar collector, a small axial fan, and a solar cell module. All parts are located on a frame made of metal. The solar collector has hexagonal channels. Its base is painted black and is directly connected to the drying tunnel. The solar collector is covered with a transparent polycarbonate sheet. A $150-\mathrm{W}$ solar cell module is installed in the dryer to move the air by means of the fan support. The collector has as surface area that is $2 \mathrm{~m}$ long and $1.9 \mathrm{~m}$ wide. The area of the drying tunnel is exactly twice the area of the collector. The solar tunnel dryer faces south in the east-west direction and does not have shade between 9:00 am and 5:00 pm.

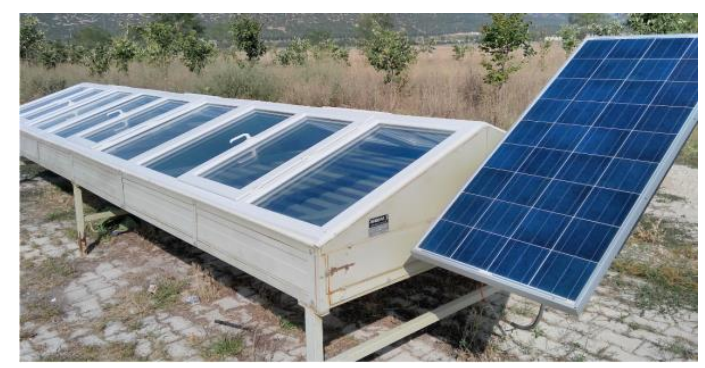

Figure 1. The experimental solar tunnel dryer

Solar radiation values were measured on a flat horizontal surface between 09:00 and 17:00 hourly with a pyranometer. In the solar tunnel type dryer, drying air temperature and relative humidity were measured by using $\mathrm{K}$ type thermocouples and DT-3 hygrometer, respectively. The velocity of the drying air, which is another drying value, was measured outside the dryer with a hotwire anemometer.

The content of moisture was calculated by drying 50 grams of zucchini in a hot air oven at $105^{\circ} \mathrm{C}$ for $24 \mathrm{~h}$. The measurement was performed three times for each experiment and averaged.

The moisture ratio (MR) of the zucchini samples was determined (1) using the Equation (1) below.

$$
M R=\frac{M_{t}-M_{e}}{M_{0}-M_{e}}
$$

where, $\mathrm{M}_{\mathrm{t}}, \mathrm{M}_{0}$, and $\mathrm{M}_{\mathrm{e}}$ are the moisture content at time $\mathrm{t}$, the initial moisture content and equilibrium moisture content of the zucchini sample $\left(\mathrm{kg}_{\text {water }} \mathrm{kg}_{\text {drymatter }}{ }^{-1}\right)$, respectively. $\mathrm{M}_{\mathrm{e}}$ is relatively small for a long drying time compared to $\mathrm{M}_{\mathrm{t}}$ or $\mathrm{M}_{0}$. Therefore, $\mathrm{Me}$ is accepted as numerically zero in this study. Thus, $M R$ can be simplified as $\mathrm{MR}=\mathrm{M}_{t} / \mathrm{M}_{0}$. (Tunckal \&Doymaz, 2020).

The drying rate was a highly significant parameter in terms of drying kinetics. In order to reveal the relationship between the drying time of the zucchini slices and the drying speed, the drying speed was determined as follows:

$$
\frac{\Delta M}{\Delta t}=\lim _{\Delta t \rightarrow 0}\left(M_{t+\Delta t}-M_{t} / \Delta_{t}\right)
$$

where $\Delta M / \Delta t$ is the drying rate $\left(\mathrm{kg}_{\text {water }} \mathrm{kg}_{\text {dry matter }}{ }^{-1} \mathrm{~min}^{-1}\right), \mathrm{M}$ is the moisture content of the sample at any time $\left(\mathrm{kg}_{\text {water }} \mathrm{kg}\right.$ dry matter 
$\left.{ }^{1}\right), \mathrm{t}$ is time (min) $\Delta \mathrm{t}$ is time increment $(\mathrm{min})$ (Kutlu and Isci, 2017).

Mathematical modeling has a great importance in Food Engineering applications as well as in other engineering applications (Robe 1990). Mathematical modeling is used to examine processes such as drying, cooling, freezing, and heating

Table 1. Mathematical models used in drying processes of agricultural products

\begin{tabular}{|c|c|c|c|}
\hline No & \multicolumn{2}{|c|}{ Mathematical models } & References \\
\hline 1 & $M R=\exp (-k t)$ & Newton & Henderson (1974) \\
\hline 2 & $M R=\exp \left(-k t^{n}\right)$ & Page & Zhang and Litchfield (1991) \\
\hline 3 & $\mathrm{MR}=\mathrm{aexp}(-\mathrm{kt})$ & Henderson and Pabis & Henderson and pabis (1961) \\
\hline 4 & $M R=a \exp (-k t)+c$ & Logarithmic & Karathanos (1999) \\
\hline 5 & $M R=a \exp (-k t)+(1-a) \exp (-k b t)$ & Diffusion & Yaldız et al. (2001) \\
\hline 6 & $M R=a \exp \left(-k\left(t^{n}\right)+b t\right.$ & Midilli et al. & Midilli et al.(2002) \\
\hline 7 & $M R=\operatorname{aexp}\left(\left(-k \cdot t^{n}\right)+(b t)\right)+g$ & Alibas & Alibas (2012) \\
\hline 8 & $\mathrm{MR}=\mathrm{a} 0 /(1+\mathrm{aexp}(\mathrm{kt}))$ & Logistic & Chandra \& Singh (1995) \\
\hline
\end{tabular}

Mathematical models were used to explain the drying properties of agricultural products. Drying curves were simulated using eight empirical models (Table 1).

The models were evaluated based on Root mean square error (RMSE), chi-squared ( $\chi 2)$, coefficient of determination $\left(\mathrm{R}^{2}\right)$, were used to determine the quality of the fit. Highest value of $\mathrm{R}^{2}$ and lower values of $\chi 2$ and RMSE were adjudged the best fit (Loague ve Green 1991, Pangavhane vd. 1999). These can be calculated as:

$R^{2}=1-\left[\frac{\sum_{i=1}^{N}\left(M R_{\text {pre }, i}-M R_{\text {exp }, i}\right)^{2}}{\sum_{i=1}^{N}\left(M R_{\text {pre }, i}-M R_{\text {pre }, i}\right)^{2}}\right]$

$\chi^{2}=\frac{\sum_{i=1}^{N}\left(M R_{\exp , i}-M R_{\text {pre }, i}\right)^{2}}{N-Z}$

$R M S E=\left[\frac{1}{N} \sum_{i=1}^{N}\left(M R_{p r e, i}-M R_{\text {exp }, i}\right)^{2}\right]^{\frac{1}{2}}$

where $M R_{\text {exp,i }}$ and $M R_{\text {pre, } i}$ are the experimental are the experimental and predicted dimensionless MR respectively, $\mathrm{N}$ is the number of observations, and $\mathrm{Z}$ is the number of drying constants.

Sigma Plot (Scientific Graph System, version 12.00) software was used to perform the statistical analysis. Non-linear regression analysis was carried out by means of Sigma-Plot (version 12.00) in order to calculate equation parameters. The results of the regression analysis include $\mathrm{R} 2, \chi^{2}$, and RMSE for microwave drying of zucchini samples under solar tunnel drying, shade and various microwave output powers. in foods (Devres and Pala, 1993). In particular quasi-theoretical and empirical models have been improved by some searchers to explain drying curves. The most used models in the drying processes of agricultural products are given in Table 1 .

\section{Results and Discussion}

Zucchini slices were dried with a solar tunnel type dryer in July in 2019. Figure 2 shows the drying air temperature pattern. During the drying experiments, the drying air temperature varied between 29.3 and $51.8^{\circ} \mathrm{C}$. The changes in solar radiation and air velocity during drying are given in figure 2 . The velocities obtained from the fans peaked at midday and ranged from approximately 0.22 to $0.88 \mathrm{~m} \mathrm{~s}^{-1}$ (Figure 2). The fan is an uncontrollable, and this fan has been running continuously due to the solar cell module supplying power. In addition, more energy obtained by the collector with excess solar radiation caused the drying air temperature to increase. Air velocity changed as a function of solar irradiation due to solar cell dependency. Solar radiation values reached their highest values at the noon time and varied between 200 and 692.67 W.m- ${ }^{2}$. Alıç and Daş (2020) presented a computational fluid dynamics (CFD) simulation of solar collectors developed especially for drying agricultural products. Air was used as the working fluid in the analysis. As a result, insolation factors of Elazig climatic conditions at some hours of the day were determined for the fixed HGK.

In the drying experiments, boiled and unboiled zucchini slices in three different slice thicknesses as 3,6,9 mm were used. With the moisture determination method applied before drying, the moisture content of the samples on wet basis was found to be $90.24 \%$ and the dry matter rate $19,45 \%$. With the drying process, the moisture content of the samples was taken to $15 \%$ on wet basis. The drying graphics of the samples after the drying process applied are given in Figure 2. As seen in Table 2, the drying times of the samples dried by applying pre-treatment (boiling) were found to be shorter than the samples dried without pre-treatment. However, the $3 \mathrm{~mm}$ slice thickness pre-treated and non-pre-treated zucchini samples dried at the same time. The reason for this can be thought to be due to the small slice thickness. 

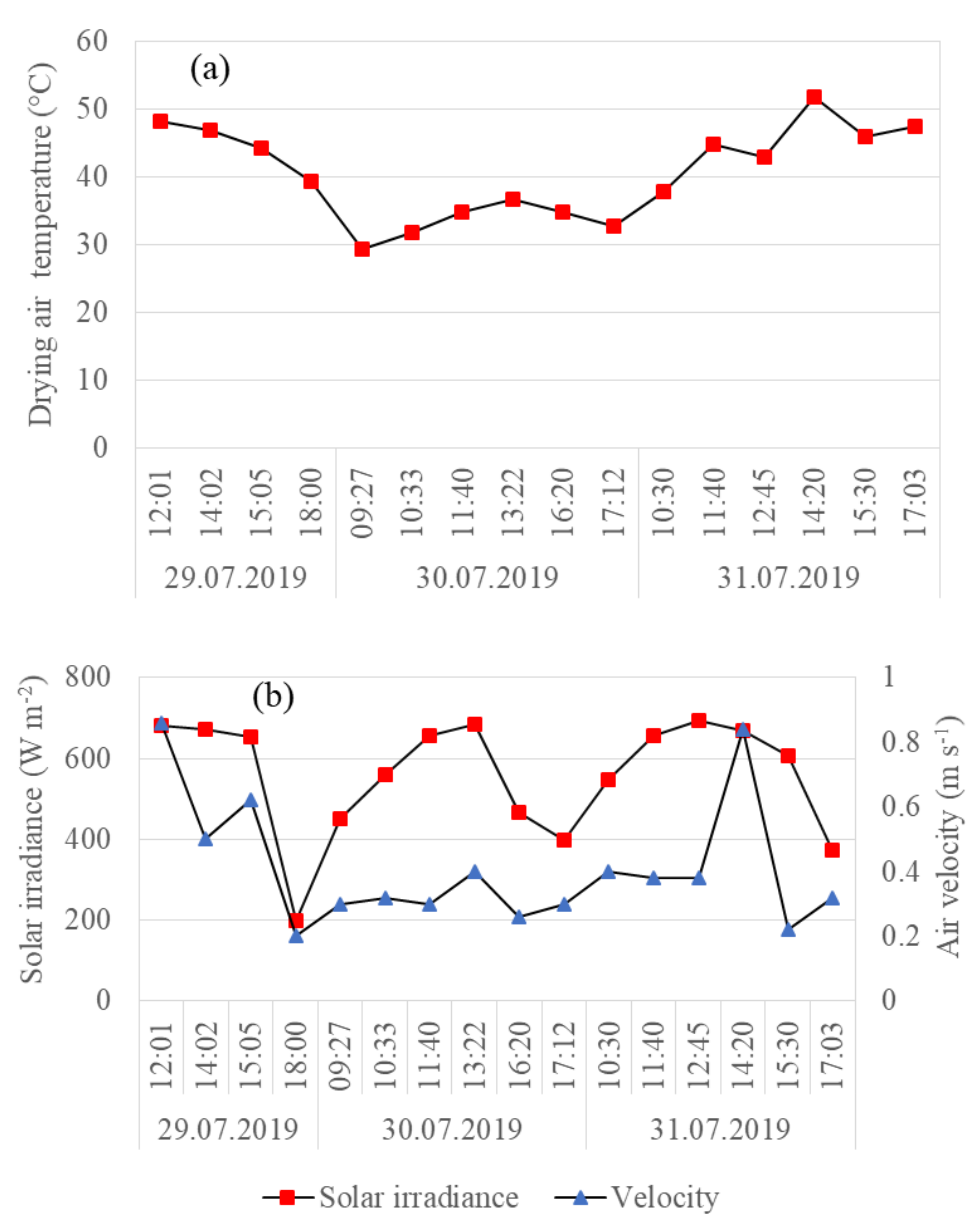

Figure 2. Change of drying air temperature (a) and solar irradiance and air velocity of drying air at the outlet of drying tunnel as a function of time

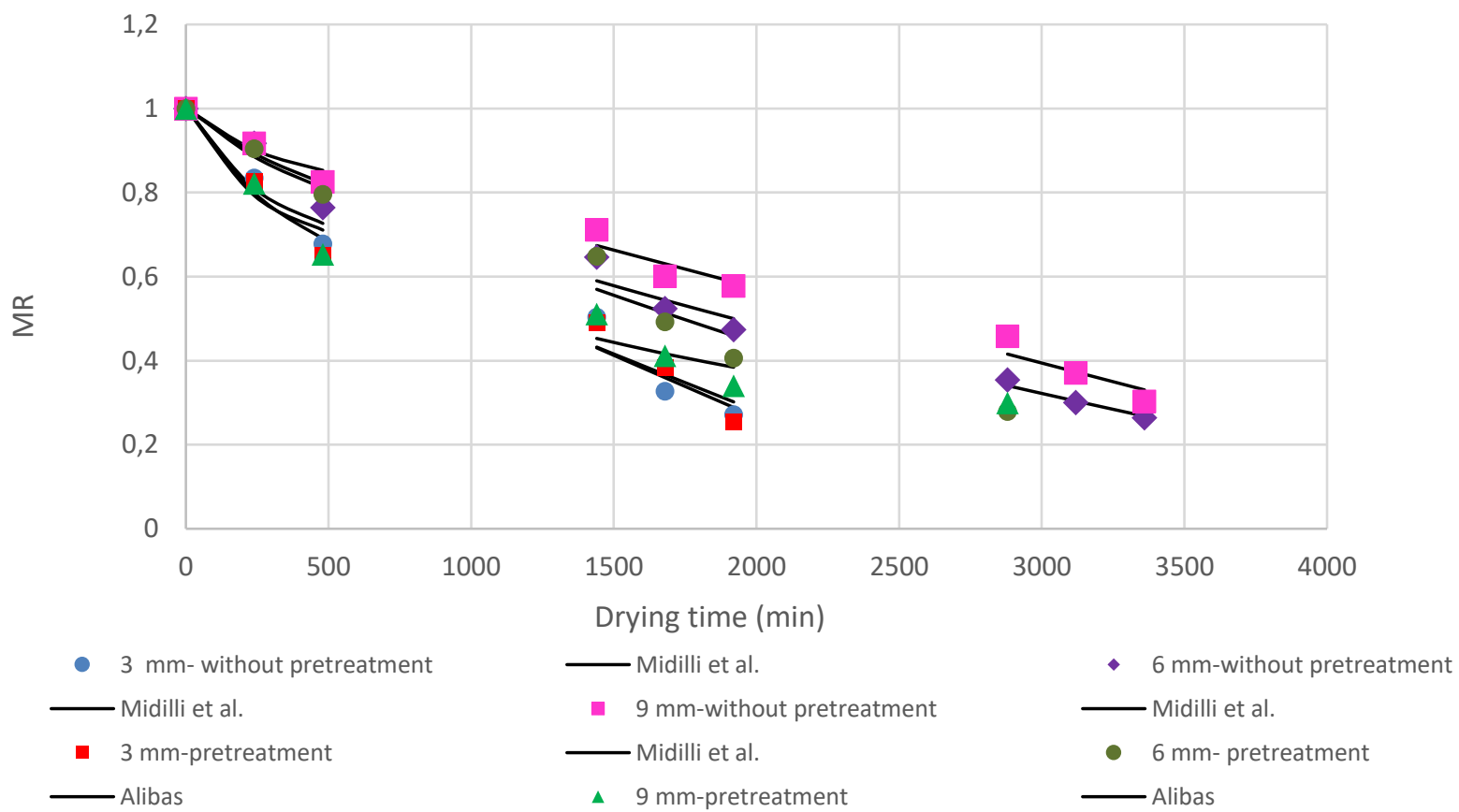

Figure 3. Comparison of the experimental curve obtained with the estimated data on the Alibas and Midilli et al. equations during zucchini drying with the solar tunnel drying method 
Total drying times of 1920, 2880 and 2880 minutes were determined for zucchini samples with 3,6 and $9 \mathrm{~mm}$ slice thickness, which were pretreated (boiled) under solar tunnel type drying conditions, respectively. On the other hand, total drying times of 1920, 3360 and 3360 minutes were determined for 3, 6, and $9 \mathrm{~mm}$ zucchini samples which were dried in the same dryer, respectively. When all results are evaluated in terms of total drying time, the expected shortest total drying time (1920 min) was obtained by drying $3 \mathrm{~mm}$ thick samples both with and without pretreatment, while the longest time (3360 min) was obtained from 6 and $9 \mathrm{~mm}$ sample thicknesses under without pretreatment drying conditions (Fig. 3). In this study, pre-treated zucchini samples were dried in a shorter time at all three sample thicknesses. Therefore, pretreatment application is important in drying works. Similar results were also reported for food products by earlier researchers. This finding shows that the drying times of the zucchini samples are affected by the product thickness rather than the temperature of the air. In the literature, there is no study examining the effect of the thickness of zucchini samples on drying. As different material, Doymaz (2014) dried the carrot in different thicknesses $(1$ and $2 \mathrm{~cm})$, different air velocities $(0.5$ and $1 \mathrm{~m} / \mathrm{s})$ and different temperatures $\left(50-70^{\circ} \mathrm{C}\right)$. In this practice, the drying time at $60^{\circ} \mathrm{C}$ was reduced by $41 \%$ by halving the thickness.
Figure 4 shows the variation of drying time and drying rate of zucchini samples dried with and without pretreatment at different slice thicknesses in a solar tunnel drying system. Accordingly, the total drying rates were determined as $\left.0.000307 \mathrm{~kg}^{2} \mathrm{H}_{2} \mathrm{O}\right] \mathrm{kg}^{-1}$ dry solids.min for $3 \mathrm{~mm}$ sample thickness, $\left.0.000152 \mathrm{~kg}^{2} \mathrm{H}_{2} \mathrm{O}\right] \mathrm{kg}^{-1} \mathrm{dry}$ solids.min for $6 \mathrm{~mm}$, and $0.000154 \mathrm{~kg}\left[\mathrm{H}_{2} \mathrm{O}\right] \mathrm{kg}^{-1}$ dry solids.min for $9 \mathrm{~mm}$ for the without pretreatment, respectively. The total drying rates to reach the final moisture content of the pretreated zucchini samples were $0.000324,0.000171$ and $0.00029 \mathrm{~kg}$ at sample thicknesses of $3 \mathrm{~mm}, 6 \mathrm{~mm}$ and $9 \mathrm{~mm}$, respectively.

All of the zucchini drying methods have occurred in the falling drying rate period. In addition, there is no constant rate drying period in the drying rate curves. Parallel effects were acquired in the study by Yaldiz et al. (2001) for sultana grape.

As the thickness decreases, the drying time decreases as the drying rate increases. At the same time, by reducing the thickness to half at the same temperature values, drying times decreased by an average of $57 \%$ for all zucchini samples. Akpınar and Biçer (2003) dried zucchini samples at 60,70 and $80^{\circ} \mathrm{C}$ in a cyclonetype dryer and similarly reported that the drying rates were in the falling rate drying period and the drying rate increased as the temperature increased.
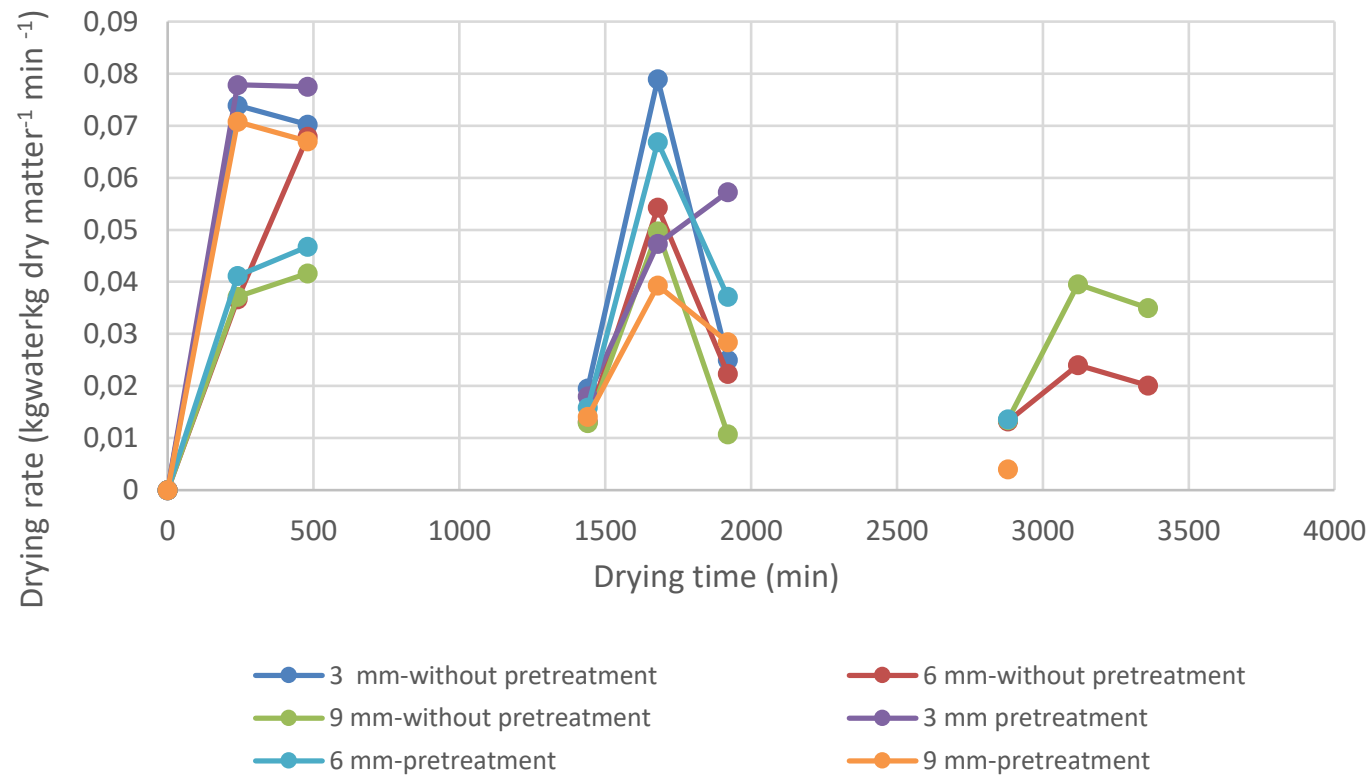

Figure 4. Variation of drying rate depending on the drying time in the solar tunnel

The drying data obtained as a result of the experiment were adapted to eight thin layer drying models (Table1). Table 2 shows the statistical results for all models for each drying application evaluated. The performance of the models used in the study was commented with respect to $\mathrm{R}^{2}, \chi^{2}$ and RMSE, which represent the coefficient of determination, reduced chi-square and the root mean square error of non-linear regression analysis, respectively. $\mathrm{R}^{2}$ value (the highest) and $\chi^{2}$ and RMSE values (the lowest) we used to determine the performance of 8 different model equations show how fit the model equation is. Statistical results for each model are shown in Table 2, $\mathrm{R}^{2}, \chi^{2}$ and RMSE were within 0,9328 to $0,9874,0,00133$ to 0,00656 and 0,02563 to 0,06271 ranges, respectively for all methods and models. Considering all selected models, Midilli et al. and Alibaş model equations give the highest $\mathrm{R}^{2}$, the lowest $\chi^{2}$ and RMSE values. 
Table 2. Estimated and statistical data obtained from drying models.

\begin{tabular}{|c|c|c|c|c|c|c|c|c|c|c|c|c|c|}
\hline Models & $\begin{array}{c}\text { Thickness of } \\
\text { Zucchini }\end{array}$ & Applications & & & & & & & & & & & \\
\hline & \multirow{3}{*}{$3 \mathrm{~mm}$} & & $\mathbf{a}$ & $\mathbf{a}_{0}$ & $\mathbf{a}_{1}$ & b & c & g & $\mathbf{k}$ & $\mathbf{n}$ & $\mathbf{R}^{2}$ & RMSE & $\chi^{2}$ \\
\hline \multirow{6}{*}{ Newton } & & Without pretreatment & - & - & - & - & - & - & 0.0006 & - & 0.9628 & 0.05062 & 0.00561 \\
\hline & & Pretreatment & - & - & - & - & - & - & 0.0006 & - & 0.9503 & 0.05695 & 0.00656 \\
\hline & \multirow{2}{*}{$6 \mathrm{~mm}$} & Without pretreatment & - & - & - & - & - & - & 0.0004 & - & 0.9825 & 0.03331 & 0.00174 \\
\hline & & Pretreatment & - & - & - & - & - & - & 0.0004 & - & 0.9704 & 0.04266 & 0.00350 \\
\hline & \multirow{2}{*}{$9 \mathrm{~mm}$} & Without pretreatment & - & - & - & - & - & - & 0.0003 & - & 0.9756 & 0.03573 & 0.00257 \\
\hline & & Pretreatment & - & - & - & - & - & - & 0.0005 & - & 0.9328 & 0.06271 & 0.00820 \\
\hline \multirow{6}{*}{ Page } & \multirow{2}{*}{$3 \mathrm{~mm}$} & Without pretreatment & - & - & - & - & - & - & 0.0016 & 0.8716 & 0.9683 & 0.04671 & 0.00546 \\
\hline & & Pretreatment & - & - & - & - & - & - & 0.0026 & 0.8006 & 0.9655 & 0.04746 & 0.00570 \\
\hline & \multirow{2}{*}{$6 \mathrm{~mm}$} & Without pretreatment & - & - & - & - & - & - & 0.0005 & 0.9628 & 0.9829 & 0.03293 & 0.00181 \\
\hline & & Pretreatment & - & - & - & - & - & - & 0.0002 & 1.0675 & 0.9714 & 0.04194 & 0.00318 \\
\hline & \multirow{2}{*}{$9 \mathrm{~mm}$} & Without pretreatment & - & - & - & - & - & - & 0.0002 & 1.0639 & 0.9765 & 0.03505 & 0.00232 \\
\hline & & Pretreatment & - & - & - & - & - & - & 0.0055 & 0.6829 & 0.9819 & 0.03256 & 0.00223 \\
\hline \multirow{6}{*}{$\begin{array}{l}\text { Henderson } \\
\text { and Pabis }\end{array}$} & \multirow{2}{*}{$3 \mathrm{~mm}$} & Without pretreatment & 0.9741 & - & - & - & - & - & 0.0006 & - & 0.9656 & 0.04866 & 0.00536 \\
\hline & & Pretreatment & 0.9608 & - & - & - & - & - & 0.0006 & - & 0.9571 & 0.05291 & 0.00592 \\
\hline & \multirow{2}{*}{$6 \mathrm{~mm}$} & Without pretreatment & 0.9866 & - & - & - & - & - & 0.0004 & - & 0.9832 & 0.03265 & 0.00173 \\
\hline & & Pretreatment & 1.0003 & - & - & - & - & - & 0.0004 & - & 0.9704 & 0.04266 & 0.00350 \\
\hline & \multirow{2}{*}{$9 \mathrm{~mm}$} & Without pretreatment & 0.9946 & - & - & - & - & - & 0.0003 & - & 0.9757 & 0.03562 & 0.00259 \\
\hline & & Pretreatment & 0.9335 & - & - & - & - & - & 0.0005 & - & 0.9528 & 0.05253 & 0.00544 \\
\hline \multirow{6}{*}{ Logarithmic } & \multirow{2}{*}{$3 \mathrm{~mm}$} & Without pretreatment & 0.9559 & - & - & - & 0.0196 & - & 0.0006 & - & 0.9656 & 0.04868 & 0.00543 \\
\hline & & Pretreatment & 0.8012 & - & - & - & 0.1779 & - & 0.0009 & - & 0.9589 & 0.05181 & 0.00656 \\
\hline & \multirow{2}{*}{$6 \mathrm{~mm}$} & Without pretreatment & 1.0916 & - & - & - & -01121 & - & 0.0003 & - & 0.9839 & 0.03201 & 0.00155 \\
\hline & & Pretreatment & 1.4380 & - & - & - & -0.4519 & - & 0.0002 & - & 0.9746 & 0.03949 & 0.00282 \\
\hline & \multirow{2}{*}{$9 \mathrm{~mm}$} & Without pretreatment & 2.4808 & - & - & - & -1.5088 & - & 0.0008 & - & 0.9836 & 0.02925 & 0.00153 \\
\hline & & Pretreatment & 0.6992 & - & - & - & 0.2802 & - & 0.0010 & - & 0.9752 & 0.03812 & 0.00302 \\
\hline
\end{tabular}


European Journal of Science and Technology

\begin{tabular}{|c|c|c|c|c|c|c|c|c|c|c|c|c|c|}
\hline Models & $\begin{array}{c}\text { Thickness of } \\
\text { Zucchini }\end{array}$ & Applications & & & & & & & & & & & \\
\hline & & & $\mathbf{a}$ & $\mathbf{a}_{0}$ & $\mathbf{a}_{1}$ & b & c & $\mathrm{g}$ & $\mathbf{k}$ & $\mathbf{n}$ & $\mathbf{R}^{2}$ & RMSE & $\chi^{2}$ \\
\hline \multirow{6}{*}{ Diffusion } & \multirow{2}{*}{$3 \mathrm{~mm}$} & Without pretreatment & 0.0603 & - & - & 0.0004 & - & - & 1.3060 & - & 0.9694 & 0.04591 & 0.00513 \\
\hline & & Pretreatment & 1.0000 & - & - & 1.0000 & - & - & 0.0006 & - & 0.9503 & 0.05695 & 0.00656 \\
\hline & \multirow{2}{*}{$6 \mathrm{~mm}$} & Without pretreatment & 1.0000 & - & - & 1.0000 & - & - & 0.0004 & - & 0.9825 & 0.03331 & 0.00174 \\
\hline & & Pretreatment & 1.0000 & - & - & 1.0000 & - & - & 0.0004 & - & 0.9704 & 0.04266 & 0.00350 \\
\hline & \multirow[b]{2}{*}{$9 \mathrm{~mm}$} & Without pretreatment & 1.0000 & - & - & 1.0000 & - & - & 0.0003 & - & 0.9756 & 0.03573 & 0.00257 \\
\hline & & Pretreatment & 1.0000 & - & - & 1.0000 & - & - & 0.0005 & - & 0.9328 & 0.06271 & 0.00820 \\
\hline \multirow{6}{*}{ Midilli et al. } & \multirow[b]{2}{*}{$3 \mathrm{~mm}$} & Without pretreatment & 1.0002 & - & - & -0.0003 & - & - & 0.0468 & 0.1899 & 0.9766 & 0.04010 & 0.00338 \\
\hline & & Pretreatment & 1.0004 & - & - & -0.0002 & - & - & 0.0464 & 0.2272 & 0.9735 & 0.04163 & 0.00367 \\
\hline & \multirow{2}{*}{$6 \mathrm{~mm}$} & Without pretreatment & 1.0032 & - & - & -0.0007 & - & - & 0.0024 & 0.6856 & 0.9866 & 0.02918 & 0.00133 \\
\hline & & Pretreatment & 0.9875 & - & - & -0.0004 & - & - & -0.0005 & 1.2366 & 0.9752 & 0.03904 & 0.00275 \\
\hline & \multirow{2}{*}{$9 \mathrm{~mm}$} & Without pretreatment & 1.0002 & - & - & -0.0002 & - & - & 0.0229 & 0.1729 & 0.9874 & 0.02563 & 0.00126 \\
\hline & & Pretreatment & 1.0021 & - & - & 0.0001 & - & - & 0.0046 & 0.7143 & 0.9821 & 0.03238 & 0.00219 \\
\hline \multirow{6}{*}{ Alibas } & \multirow{2}{*}{$3 \mathrm{~mm}$} & Without pretreatment & 1.0577 & - & - & 0.9994 & - & -6.0711 & 0.9996 & 1.0000 & 0.9717 & 0.04413 & 0.00449 \\
\hline & & Pretreatment & 2.1661 & - & - & 0.9996 & - & -1.1775 & 1.0003 & 0.9999 & 0.9668 & 0.04654 & 0.00524 \\
\hline & \multirow{2}{*}{$6 \mathrm{~mm}$} & Without pretreatment & -0.5352 & - & - & 0.0004 & - & 1.0277 & 0.8740 & -0.0008 & 0.9387 & 0.06238 & 0.00630 \\
\hline & & Pretreatment & 1.7263 & - & - & -0.0002 & - & -0.7263 & 0.0195 & 0.0007 & 0.9757 & 0.03864 & 0.00278 \\
\hline & \multirow{2}{*}{$9 \mathrm{~mm}$} & Without pretreatment & -0.4417 & - & - & 0.0004 & - & 1.0282 & 0.9175 & -0.0002 & 0.9651 & 0.04273 & 0.00255 \\
\hline & & Pretreatment & 1.2445 & - & - & 0.0009 & - & -0.2427 & 0.0033 & 0.8693 & 0.9822 & 0.03223 & 0.00219 \\
\hline \multirow{6}{*}{ Logistic } & \multirow{2}{*}{$3 \mathrm{~mm}$} & Without pretreatment & -2.2735 & -1.2604 & - & - & - & - & 0.0004 & - & 0.9670 & 0.04767 & 0.00564 \\
\hline & & Pretreatment & -0.0008 & -0.0089 & - & - & - & - & 0.0006 & - & 0.9571 & 0.05291 & 0.00592 \\
\hline & \multirow{2}{*}{$6 \mathrm{~mm}$} & Without pretreatment & 5.2287 & 6.1119 & - & - & - & - & 0.0004 & - & 0.9834 & 0.03244 & 0.00163 \\
\hline & & Pretreatment & 1.8444 & 0.8818 & - & - & - & - & 0.0007 & - & 0.9743 & 0.03972 & 0.00275 \\
\hline & \multirow{2}{*}{$9 \mathrm{~mm}$} & Without pretreatment & 0.7185 & 1.6688 & - & - & - & - & 0.0005 & - & 0.9816 & 0.03104 & 0.00177 \\
\hline & & Pretreatment & -0.0002 & -0.0001 & - & - & - & - & 0.0005 & - & 0.9528 & 0.05253 & 0.00544 \\
\hline
\end{tabular}




\section{Conclusions and Recommendations}

This study investigated the drying properties of without pretreatment and pretreatment zucchini samples in different slice thicknesses at varying air temperatures. The drying of zucchini samples at each temperature took place in the falling rate period; the study found out no constant rate period of drying. This study used the experimental data for without pretreatment and pretreatment zucchini samples in order to assess various thinlayer drying models. Of these, the Alibas and Midilli et al. model equations produced optimum results among all zucchini samples of three different slice thicknesses, dried with and without pretreatment. The association of the model parameters and the drying conditions was revealed and reported in order to estimate the moisture ratio according to the drying time.

\section{References}

Akpınar E., Biçer Y. (2003). Investigation of Drying Behaviour of Pumpkin in a Cyclone Type Dryer, Gazi University Journal of Science, 16(1), pp: 159-169.

Alibaş, İ. (2012). Microwave Drying of Grapevine (Vitis vinifera L.) Leaves and Determination of Some Quality Parameters. Journal of Agricultural Sciences, 18 (1), 43-53. Thompson Seedless Grapes. Journal Food Engineering, Vol. 39; pp. 211 216.

Alıç, E., Daş, M. (2020). Experimental Design and Numerical Analysis of a Trapezoidal Absorber Plate Air Solar Collector. European Journal of Science and Technology. Special Issue, pp. 78-88, November 2020.

Banout J., Ehl P., Havlik J., Lojka B., Polesny Z., Verner V. (2011). Design and performance evaluation of a Double-pass solar drier for drying of red chili (Capsicum annum L.). Sol. Energy, 85, pp.506-515.

Chandra, P.K., \& Singh, R. P. (1995). Applied numerical methods for food and agricultural engineers. Boca Raton, FL: CRC Press, pp. 163- 167.

Çetin, N. (2019). Effect of Drying Conditions on Color Properties of Apples and Oranges. European Journal of Science and Technology No. 17, pp. 463-470.

Devres, Y.O., Pala M. (1993). Importance and application areas of mathematical modelling in food industry. Food. 18 (3) pp: 173-181.

Doymaz, I. (2014). Convective air drying characteristics of thin layer carrots, Journal of Food Engineering, Volume 61, Issue 3, Pages 359-364.

FAOSTAT, (2020). http://www.fao.org/faostat/

Henderson, S.M., Pabis, S. (1961). Grain drying theory I: Temperature effect on drying coefficient. Journal of Agricultural Research Engineering, 6, 169-174.

Henderson S.M. (1974) Progress in developing the thin layer drying equation. Transactions of the ASAE 17: 1167-1172.

Karathanos V.T. (1999). Determination of water content of dried fruits by drying kinetics. J Food Eng 39: 337-344.

Karthikeyan A.K., Murugavelh S. (2018). Thin layer drying kinetics and exergy analysis of turmeric (Curcuma longa) in a mixed mode forced convection solar tunnel dryer. Renewable Energy. Vol: 128, Part A, Pp: 305-312.

Kutlu N. (2013). Determination And Modeling of Tomato, Zucchini and Eggplant's Drying Characteristics. Master Thesis. Ankara University Graduate School of Natural and Applied Science Department of Food Engineering. Pp:135
Kutlu N., Isci A. (2017). Drying Characteristics of Zucchini and Empirical Modeling of Its Drying Process. International Journal of Food Studies IJFS. Volume 6 pages 232-244.

Loague, K. and Green, R.E. 1991. Statistical and Graphical Methods for Evaluating Solute Transport Models. Overview and Application. J. Contam, Hydrol., Vol:7; pp. 51-73.

Midilli A, Kucuk H \& Yapar Z (2002). A new model for single layer drying. Drying Technology 20(7):1503-1513

Mulato, S., Atmawinata, O., Yusianto, Handaka, Pass, T., Muehlbauer, W., Esper, A. (1999). Development of a Solar Cocoa Processing Center for Cooperative Use in Indonesia, The Planter, 75(875), pp. 57-74.

Pangavhane, D.R., Sawhney, R.L. and Sarsavadia, P.N. (1999) Effect of various dipping pretreatment on drying kinetics of Thompson seedless grapes. Journal of Food Engineering, 39, 211-216.

Rabha, D.K. Muthukumar, P, Somayaji C. (2017). Experimental investigation of thin layer drying kinetics of ghost chili pepper (Capsicum Chinense Jacq.) dried in a forced convection solar tunnel dryer. Renew. Energy, 105 (2017), pp. 583-589.

Rabha, D.K., Muthukumar P. (2017). Performance studies on a forced convection solar dryer integrated with a paraffin wax based latent heat storage system. Sol. Energy, 149 (2017), pp. 214-226

Robe, K. 1990. CIM-The big Picture, 1980's: Computer Integrated Manufacturing, 1990's: Computer Integrated Management. Food Processing, Putman Publication, pp. 3748.

Tunckal C., İ. Doymaz (2020) Performance analysis and mathematical modelling of banana slices in a heat pump drying system. Renewable Energy. 150, 918-923.

Yaldiz O., Ertekin C., \& Uzun, H. I. (2001). Mathematical modelling of thin layer solar drying of Sultana grapes. Energy, 26(5), 457- 465.

Zhang Q, Litchfleld J.B. (1991) An optimization of intermittent corn drying in a laboratory scale thin layer dryer. Dry Technol 9: 383-395. 